\title{
AKIBAT HUKUM PENGGUNAAN SISTEM PUBLIKASI NEGATIF BERUNSUR POSITIFDALAM PENDAFTARAN TANAH DI KOTA SEMARANG
}

\author{
Fina Ayu Safitri, Lita Tyesta ALW., Anggita Doramia Lumbanraja \\ Magister Kenotariatan, Universitas Diponegoro \\ Fakultas Hukum, Universitas Diponegoro \\ Email : finaayusafitri@gmail.com
}

\begin{abstract}
Certificate of land is proof of ownership of a land, the holder could lose the rights if there is a lawsuit from another person. The purpose of this research is to find out why a certificate of land still can be changed, problems from negative publication system and how to solve it, and the consequences of a negative publication system. The method of this research is empirical juridical. The results of the research shows that certificates can still be changed because the publicity system used is positive negative, certificates of land are strog but not absolute proof. The problem from negative publication system is the lack of legal certainty for landowners listed in the certificate. The legal consequence of using a negative publication system in land registration is if it is proven that the owner obtained the land by violating the principle of nemo plus juris and not in good faith, the ownership and rights can be erased. Although the publication system in Indonesia is negative with positive element, the positive element has not yet been realized, because in land registration it is nearly pure negative, so the legal guarantee for land owners is still lacking.
\end{abstract}

\section{Keywords: publication system; land registry}

\begin{abstract}
Abstrak
Sertipikat hak atas tanah merupakan bukti kepemilikan atas tanah, namun pemegangnya masih dapat kehilangan haknya atas tanah tersebut apabila ada gugatan dari pihak lain. Tujuan dari penelitian ini adalah untuk mengetahui mengapa suatu sertipikat hak atas tanah masih dapat diubah, masalah yang timbul dari penggunaan sistem publikasi negatif dan bagaimana penanggulangannya, serta akibat hukum dari sistem publikasi negatif dalam pendaftaran tanah. Metode yang digunakan dalam penelitian ini adalah yuridis empiris.Hasil dari penelitian menunjukkan sertipikat hak atas tanah masih dapat diubah karena sistem publikasi yang digunakan adalah negatif berunsur positif, sertipikat hak atas tanah merupakan alat bukti yang kuat, bukan alat bukti yang mutlak. Masalah yang timbul dari penggunaan sistem publikasi negatif yaitu kurangnya kepastian hukum bagi pemilik tanah yang tercantum di sertipikat. Akibat hukum penggunaan sistem publikasi negatif dalam pendaftaran tanah yaitu apabila terbukti bahwa pemilik memperoleh tanah dengan melanggar asas nemo plus juris dan tidak beritikad baik, maka kepemilikan dan hak atas tanahnya dapat hapus. Berdasarkan hasil penelitian ini,meskipun sistem publikasi yang digunakan di Indonesia merupakan sistem publikasi negatif berunsur positif, namun unsur positifnya belum terwujud, karena yang digunakan dalam pendaftaran tanah mendekati negatif murni, sehingga jaminan kepastian hukum bagi pemilik tanah masih kurang.
\end{abstract}

\section{Kata kunci: sistem publikasi; pendaftaran tanah}

\section{A. Pendahuluan}

Tanahmerupakansalah satu kebutuhan terpenting bagi manusia, tidak hanya untuk mendirikan bangunan tempat tinggal, namun juga untuk melakukan segala aktivitas kehidupan 
sehari-harinya. Pasal 33 ayat (3) Undang-Undang Dasar Negara Republik Indonesia (UUD NRI) Tahun 1945 yang menyebutkan bahwa "Bumi, air serta kekayaan alam yang terkandung di dalamnya dikuasai negara dan dipergunakan untuk sebesar-besarnya kemakmuran rakyat”.(Undang-undang Dasar Negara Republik Indonesia Tahun 1945, n.d.)Setiap individu mempunyai kepentingan yang berbeda-beda atas suatu tanah, sehingga Pemerintah merasa perlu dibuat peraturan-peraturan yang melindungi hak dan kewajiban setiap individu tersebut.

Pendaftaran tanah dalam bahasa latin disebut Capistratum yang berarti suatu register atau capita atau unit yang diperbuat untuk pajak tanah Romawi (Capotatio Terrens). Cadastremerupakan data lahan-lahan, nilai dari suatu tanah, pemegang haknya untuk kepentingan perpajakan, makacadastre merupakan alat yang tepat untuk memberikan uraian dan identifikasi dari hak atas tanah(Santoso, 2010).

Pemerintah bertekad memberikan jaminan kepastian hukum bagi kepemilikan tanah di Indonesia, maka dibuatlah peraturan yang mengatur mengenai kepemilikan tanah, yaitu Undang-undang Nomor 5 Tahun 1960 tentang Peraturan Dasar Pokok-pokok Agraria (UUPA). Pemberian jaminan kepastian hukum yang dimaksud adalah dengan tersedianya hukum tertulis dan penyelenggaraan pendaftaran tanah yang efektif.(Harsono, 2008)

Pasal 19 ayat (1) UUPAyang mennentukan bahwa, "untuk menjamin kepastian hukum oleh Pemerintah diadakan pendaftaran tanah diseluruh wilayah Republik Indonesia menurut ketentuan-ketentuan yang diatur dengan Peraturan Pemerintah".(Undang-undang Nomor 5 Tahun 1960 tentang Peraturan Dasar Pokok-pokok Agraria, n.d.)

Untuk mewujudkan amanat Pasal 19 UUPA tersebut, terbitlah PP Nomor 10 Tahun 1961 yang mengatur tentang pendaftaran tanah. PP tersebut mengatur tentang proses pendaftaran tanah di Indonesia dan akibat hukumnya dengan produk akhir adalah diterbitkannya surat tanda bukti hak yang disebut dengan sertifikat tanah.

Selama perjalanan PP tersebut dirasa belum dapat mencapai apa yang dicita-citakan oleh UUPA, karena baru lebih kurang $45 \%$ bidang tanah yang terdaftar pada waktu itu, sehingga PP tersebut dicabut dan disempurnakan oleh PP Nomor 24 Tahun 1997.Menurut Pasal 1 angka 1 Undang-undang Nomor 24 Tahun 1997, "Pendaftaran tanah adalah rangkaian kegiatan yang dilakukan oleh Pemerintah secara terus menerus, berkesinambungan dan teratur, meliputi pengumpulan, pengolahan, pembukuan, dan penyajian serta pemeliharaan data fisik dan data yuridis, dalam bentuk peta dan daftar, mengenai bidang-bidang tanah dan satuan-satuan rumah susun, termasuk pemberian surat tanda bukti haknya bagi bidang-bidang tanah yang sudah ada haknya dan hak milik atas satuan rumah susun serta hak-hak tertentu yang membebaninya." (Peraturan Pemerintah Nomor 24 Tahun 1997 tentang Pendaftaran Tanah, n.d.) 
Data mengenai letak, batas, danluas bidang tanah serta satuan rumah susun yang didaftar, termasuk ada tidaknya bangunan di atasnya disebut data fisik. Data yangberisi keterangan mengenai status hukum bidang tanah dan satuan rumah susun yang didaftar, pemegang haknya dan pihak lain serta beban-beban lain yang membebaninya disebut data yuridis(Santoso, 2014).

Jadi, proses pendaftaran tanah menghasilkan sertipikat hak atas tanah yang terdiri dari salinan Buku Tanah yang memuat data yuridis, kemudian dilampiri Surat Ukur yang memuat data fisik, lalu dijilid menjadi satu dan diberi sampul berwarna hijau bergambar burung garuda.

Untuk menguji daya kekuatan sertipikat tersebut, dalam pendaftaran tanah juga dikenal sistem publikasi. Sistem publikasi digunakan untuk menguji daya kekuatan pembuktian sertipikat, yaitu kuat atau tidak kuat dan mutlak atau tidak mutlak. Terdapat dua jenis sistem publikasi yaitu sistem publikasi positif dan sistem publikasi negatif.

Sistem publikasi positif menggunakan sistem pendaftaran hak, maka harus ada Register atau Buku Tanah untuk penyimpanan dan penyajian data yuridis, sedangkan sertipikat sebagai surat tanda bukti hak. Pencatatan nama seseorang daam register sebagai pemegang hak membuat seseorang menjadi pemegang hak atas tanah yang bersangkutan, bukan perbuatan hukum pemindahan hak yang dilakukan (Tittle by registration, The Register is everything). Pernyataan tersebut merupakan dasar falsafah yang melandasi sistem Torrens, yaitu dengan sistem publikasi positif ini negara menjamin kebenaran data yang disajikan(Harsono, 2008).

Jika suatu negara menggunakan sistem publikasi positif, maka sertipikat yang dikeluarkan daya pembuktiannya adalah mutlak. Karena daya pembuktiannya adalah mutlak, akibatnya terhadap sertipikat yang dikeluarkan negara tersebut tidak dapat diajukan gugatan, sehingga tidak dapat dilakukan perubahan terhadap sertipikat hak atas tanah tersebut.

Pada sistem publikasi negatif, sahnya perbuatan hukum yang dilakukan yang menentukan berpindahnya hak kepada pembeli, bukan pendaftarannya. Pendaftaran tidak membuat orang yang memperoleh tanah dari pihak yang tidak berhak menjadi pemegang haknya yang baru. Dalam sistem publikasi negatif berlaku asas nemo plus juris, yaitu orang tidak dapat menyerahkan atau memindahkan hak melebihi apa yang dia sendiri punya, oleh karena itu negara tidak menjamin kebenaran data yang disajikan. Meskipun pendaftaran telah dilakukan, pembeli masih dimungkinkan mendapat gugatan dari orang yang memiliki bukti bahwa dialah pemegang hak yang sebenarnya(Harsono, 2008).

Sistem publikasi negatif dapat melindungi pemegang hak yang sebenarnya, karena pemegang hak yang sebenarnya dapat menuntut kembali haknya meskipun telah terdaftar atas nama orang lain(Sutedi, 2010). 
Jadi dengan demikian, suatu negara yang menggunakan sistem publikasi negatif masih dimungkinkan untuk diajukan gugatan terhadap suatu sertipikat hak atas tanah, sehingga data yang ada pada sertipikat masih dapat diubah sewaktu-waktu.

Dari kedua jenis sistem publikasi tersebut, Indonesia memilih di antara keduanya. Indonesia tidak menggunakan sistem publikasi positif murni, namun tidak juga menggunakan sistem publikasi negatif murni.

Pasal 19 UUPA secara tersirat menyatakan bahwa Indonesia menggunakan sistem publikasi negatif, namun dengan unsur-unsur positif yang mengikuti, sehingga daya pembuktian sertipikat di Indonesia bukan mutlak atau tidak mutlak, melainkan kuat. Jadi, sertipikat hak atas tanah merupakan alat pemuktian yang kuat atas kepemilikan suatu tanah. Maksud dari sertipikat merupakan alat bukti yang kuat yaitu sepert yang dinyatakan dalam penjelasan Pasal 32 PP Nomor 24 Tahun 1997, yaitu:

"Sertifikat merupakan tanda bukti hak yang kuat, dalam arti bahwa selama tidak dapat dibuktikan sebaliknya data fisik dan data yuridis yang tercantum di dalamnya harus diterima sebagai data yang benar. Sudah barang tentu data fisik maupun data yuridis yang tercantum dalam sertifikat harus sesuai dengan data yang tercantum dalam buku tanah dan surat ukur yang bersangkutan, karena data itu diambil dari buku tanah dan surat ukur tersebut".(Peraturan Pemerintah Nomor 24 Tahun 1997 tentang Pendaftaran Tanah, n.d.)

Adanya ketentuan tersebut, maka artinya sertipikat hak atas tanah masih dapat dibatalkan, oleh sebab itu banyak yang mengajukan pembatalan sertipikat karena ketentuan dalam peraturan tersebut memperbolehkan demikian, sehingga masih sangat banyak sengketa yang terjadi akibat penggunaan sistem publikasi negatif berunsur positif di Indonesia. Ketentuan ini membukakesempatan kepada orang lain untuk menggugat orang yang sudah memiliki sertipikat(Kaunang, 2016).

Pada tahun 2013-2016, terdapat 7 (tujuh) gugatan mengenai sertipikat yang telah diputus oleh Hakim Pengadilan Negeri Semarang. Sedangkan untuk pembatalan sertipikat, pada tahun 2013-2016 terdapat 117 perkara yang telah diputus oleh Hakim Pengadilan Tinggi Tata Usaha Negara Semarang. Oleh sebab itu, maka penulisan hukum ini akan difokuskan pada Kota Semarang, dengan judul "Akibat Hukum Penggunaan Sistem Publikasi Negatif dalam Pendaftaran Tanah (Studi di Kota Semarang)”.

Peraturan yang mengatur mengenai kepemilikan tanah, yaitu Undang-undang Nomor 5 Tahun 1960 tentang Peraturan Dasar Pokok-pokok Agraria (UUPA), memberikan jaminan kepastian hukum dengan tersedianya hukum tertulis dan penyelenggaraan pendaftaran tanah yang efektif(Harsono, 2008). 
Pasal 19 UUPA menentukan bahwa untuk menjamin kepastian hukum oleh Pemerintah dilakukan pendaftaran tanah di seluruh wilayah Republik Indonesia, maka terbitlah PP Nomor 10 Tahun 1961 yang mengatur tentang pendaftaran tanah. PP tersebut mengatur tentang proses pendaftaran tanah di Indonesia dan akibat hukumnya dengan produk akhir adalah diterbitkannya surat tanda bukti hak yang disebut dengan sertifikat tanah.(Peraturan Pemerintah Nomor 10 Tahun 1961 tentang Pendaftaran Tanah, n.d.)

PP Nomor 10 Tahun 1961 tersebut dicabut dan disempurnakan oleh PP Nomor 24 Tahun 1997 tentang Pendaftaran Tanah.Menurut Pasal 1 angka 1 Undang-undang Nomor 24 Tahun 1997, "Pendaftaran tanah adalah rangkaian kegiatan yang dilakukan oleh Pemerintah secara terus menerus, berkesinambungan dan teratur, meliputi pengumpulan, pengolahan, pembukuan, dan penyajian serta pemeliharaan data fisik dan data yuridis, dalam bentuk peta dan daftar, mengenai bidang-bidang tanah dan satuan-satuan rumah susun, termasuk pemberian surat tanda bukti haknya bagi bidang-bidang tanah yang sudah ada haknya dan hak milik atas satuan rumah susun serta hak-hak tertentu yang membebaninya".(Peraturan Pemerintah Nomor 24 Tahun 1997 tentang Pendaftaran Tanah, n.d.)

Penggunaan sistem publikasi negatif berunsur positif memiliki kelebihan sekaligus kelemahan. Kelebihan penggunaan sistem publikasi negatif berunsur positif yaitu kepemilikan tanah adat lebih terlindungi, banyaknya tanah adat di Indonesia membuat segelintir orang yang tidak beritikad baik memanfaatkan situasi untuk memalsukan data, sehingga dapat terbit sertipikat hak atas tanah yang sebenarnya merupakan tanah adat. Adanya penggunaan sistem publikasi negatif dalam pendaftaran tanah, mengakibatkan sertipikat tersebut masih bisa dibatalkan, sehingga pemilik sebenarnya tetap dapat dilindungi. Adapun kelemahan penggunaan sistem publikasi negatif berunsur positif yaitu meskipun seseorang telah memiliki sertipikat hak atas tanah, ia masih rentan terhadap gugatan terkait dengan sertipikat hak atas tanah tersebut.

Sertipikat hak atas tanah merupakan alat pembuktian yang kuat atas kepemilikan suatu tanah. Maksud dari sertipikat merupakan alat bukti yang kuat yaitu seperti yang dinyatakan dalam penjelasan Pasal 32 PP Nomor 24 Tahun 1997,selama tidak dapat dibuktikan sebaliknya maka data fisik dan data yuridis yang tercantum di dalam sertipikat harus dianggap benar. (Peraturan Pemerintah Nomor 24 Tahun 1997 tentang Pendaftaran Tanah, n.d.)

Hal tersebut menunjukkan bahwa sistem publikasi dalam pendaftaran tanah yang digunakan bukan sistem positif, karena dalam sistem publikasi positif, alat bukti yang dihasilkan mempunyai sifat "mutlak", begitu sebaliknya dengan menyatakan alat bukti tersebut 
sebagai alat bukti yang "kuat" ini menunjukan bukan sistem negatif yang murni(Widyani, 2015).

Dari penjabaran mengenai sistem publikasi dalam pedaftaran tanah di atas, maka dalam penelitian ini dapat dirumuskan dua permasalahan yaitu masalah apa saja yang timbul dari penerapan sistem pubikasi negatif tersebut, dan bagaimana Kantor Pertanahan Kota Semarang menanggulanginya. Kemudian permasalahan yang kedua adalah apa saja akibat hukum yang timbul dari sistem publikasi negatif dalam pendaftaran tanah.

Sebelumnya juga telah dilakukan penelitian oleh beberapa penulis jurnal lain mengenai sistem publikasi dalam pendaftaran tanah. Jurnal yang ditulis oleh Bronto Susanto yang membahas mengenai sejauh mana suatu sertipikat hak atas tanah menjamin kepastian hukum sebagai tanda bukti hak yang kuat namun tidak mutlak karena sistem publikasi pendaftaran tanah di Indonesia yang menggunakan sistem publikasi negatif berunsur positif.(Susanto, 2014) Selain itu jurnal yang ditulis oleh Fitroh Oelom yang membahas mengenai kepastian hukum sertipikat hak atas tanah yang didaftar menggunakan sistem negatif bertendensi positif(Oelom, 2015). Kemudian jurnal yang ditulis oleh Fitri Widayanti yang membahas mengenai sejauh mana data yuridis dan data fisik yang ada di dalam sertipikat hak atas tanah dapat dipercaya ketika digunakan untuk melakukan suatu perbuatan hukum(Widayanti, 2015). Meskipun penelitian ini juga membahas mengenai sistem publikasi pendaftaran hak atas tanah seperti 3 (tiga) penelitian tersebut, namun terdapat unsur kebaharuan di dalamnya, yaitu penelitian ini membahas mengenai akibat hukum bagi pemegang sertipikat hak atas tanah dari penggunaan sistem publikasi negatif berunsur positif dalam pendaftaran tanah yang berlaku.

\section{B. Metode Penelitian}

Metode pendekatan yang digunakan dalam penelitian ini adalah metode pendekatan yuridis empiris. Metode yuridis atau tinjauan dari segi hukum tersebut adalah untuk mengetahui peraturan-peraturan yang berlaku, khususnya peraturan-peraturan yang berkaitan dengan penerapan sistem publikasi negatif terhadap pendaftaran tanah di Kota Semarang. Pendekatan empiris digunakan karena dalam membahas permasalahan dalam penelitian ini tidak hanya digunakan teori-teori saja, melainkan juga harus melihat fakta-fakta yang ada dan mengadakan pendekatan langsung pada masyarakat yang berkaitan dengan obyek yang diteliti. Pendekatan langsung pada masyarakat yang berkaitan dengan obyek yang diteliti antara lain dilakukan dengan mewawancarai Hakim Pengadilan Negeri Semarang, Hakim Pengadilan Tata Usaha Negara Semarang, Staff Badan Pertanahan Nasional Semarang, Staff Kantor Wilayah 
Badan Pertanahan Nasional Propinsi Jawa Tengah, dan juga Dosen Sekolah Tinggi Ilmu Pertanahan Yogyakarta.

Penelitian ini menggunakan data primer dan data sekunder. Data Primer dalam penelitian ini diperoleh dari penelitian lapangan, yaitu dengan memperoleh data langsung dengan melakukan wawancara terhadap hakim Pengadilan Negeri Semarang, hakim Pengadilan Tata Usaha Negara Semarang, Kepala Badan Pertanahan Nasional Semarang, Kepala Kantor Pertanahan, serta para akademisi yang terkait dengan permasalahan penulisan hukum ini.

Data sekunder dalam penelitian hukum terdiri dari bahan hukum primer, bahan hukum sekunder, dan bahan hukum tersier. Dalam penelitian ini, akan digunakan ketiga bahan hukum tersebut. Bahan hukum primer, yaitu bahan-bahan hukum yang memiliki kekuatan mengkat mengikat, dalam penelitian ini bahan hukum primer yang digunakan adalah Peraturan Perundang-undangan, yang meliputi Undang-Undang Nomor 5 Tahun 1960 tentang Peraturan Dasar Pokok-pokok Agraria, Peraturan Menteri Agraria Nomor 6 Tahun 1965 tentang Pedoman-pedoman Pokok Penyelenggaraan Pendaftaran Tanah, Peraturan Pemerintah Nomor 24 Tahun 1997 tentang Pendaftaran Tanah, Peraturan Menteri Agraria Nomor 3 Tahun 1997 tentang Ketentuan Pelaksanaan Peraturan Pemerintah Nomor 24 Tahun 1997 tentang Pendaftaran Tanah. Bahan Hukum sekunder terdiri dari buku-buku teks hukum agraria, jurnaljurnal tentang pendaftaran tanah dan sistem publikasi, bahan rujukan lainnya tentang pendaftaran tanah dan sistem publikasi.

\section{Hasil Dan Pembahasan}

\section{Masalah yang Timbul dari Penerapan Sistem Publikasi Negatif dan Upaya Kantor Pertanahan dalam Menanggulanginya}

Sistem publikasi digunakan untuk menguji daya kekuatan pembuktian sertipikat, yaitu kuat atau tidak kuat dan mutlak atau tidak mutlak. Terdapat dua jenis sistem publikasi yaitu sistem publikasi positif dan sistem publikasi negatif. Sebagaimana diatur dalam UUPA, pendaftaran tanah di Indonesia menggunakan sistem publikasi negatif berunsur positif, artinya Indonesia tidak menggunakan sistem publikasi positif murni, namun tidak juga menggunakan sistem publikasi negatif murni.

Salah satu karakteristik sistem publikasi negatif adalahpendaftaran hak atas tanah tidak meerupakan jaminan pada nama yang terdaftar dalam buku tanah. Dengan kata lain, buku tanah bisa saja berubah sepanjang dapat membuktikan bahwa pemilik tanah yang sesungguhnya melalui putusan pengadilan yang sudah berkekuatan hukum tetap(Effendie, 1993). 
Ketika melakukan pendaftaran tanah, yang pertama kali didaftarkan adalah objeknya, yang kedua adalah kepemilikannya yang dilekati dengan hak atas tanah. Seseorang yang mendaftarkan tanahnya, biasanya ingin mendaftarkan kepemilikannya. Selain mendaftarkan kepemilikannya, ada pula yang hanya mendaftarkan hak atas tanahnya saja. Sering kali kepemilikan dan hak atas tanah dianggap sama, padahal keduanya merupakan dua hal yang berbeda. Hak atas tanah dapat hapus karena sebab-sebab yang telah diatur di dalam undangundang atau dicabut oleh Kantor Pertanahan karena menelantarkan tanah, sedangkan kepemilikan tidak bisa serta merta dicabut.

Masalah utama terkait dengan penggunaan sistem publikasi negatif ini adalah kurangnya kepastian hukum bagi pemilik tanah, karena meskipun telah tercantum sebagai pemilik tanah di dalam sertipikat, namun pemilik tanah masih dapat menghadapi kemungkinan untuk digugat oleh pihak yang merasa berkepentingan atas tanah tersebut.

Pendafaran tanah di Indonesia menggunakan sistem publikasi negatif, sehingga negara tidak menjamin kebenaran data yang disajikan, namun bukan menggunakan sistem publikasi negatif murni, melainkan sistem publikasi negatif berunsur positif.

Kebaikan dari sistem publikasi negatif adalah adanya perlindungan pada pemegang hak yang sebenarnya dan adanya penyelidikan riwayat tanah sebelum sertipikatnya diterbitkan(Sutedi, 2014).

Menurut Pasal 32 ayat (2) PP Nomor 24 Tahun 1997, apabila telah diterbitkan sertipikat suatu bidang tanah atas nama seseorang atau badan hukum yang memperoleh tanah tersebut dengan itikad baik, maka apabila ada pihak lain yang merasa memiliki tanah tersebut tetapi dalam waktu 5 (lima) tahun sejak diterbitkan sertipikat tidak mengajukan keberatan tertulis kepada Kepala Kantor Pertanahan, maka ia tidak dapat lagi menggugat haknya atas tanah tersebut.(Peraturan Pemerintah Nomor 24 Tahun 1997 tentang Pendaftaran Tanah, n.d.)

Penulis melakukan wawancara terhadap Suroso selaku Kepala Urusan Pendaftaran Tanah Badan Pertanahan Nasional Kota Semarang, menurut beliau penggunaan sistem publikasi negatif berunsur positif ini mengakibatkan kurangnya jaminan kepastian hukum bagi pemilik tanah. Seseorang yang berkepentingan dapat dengan mudah mengajukan blokir terhadap kepemilikan tanah, namun demikian dengan sistem publikasi negatif berunsur positif ini masyarakat mempunyai kesempatan yang sama untuk membuktikan sebaliknya terhadap kepemilikan suatu tanah(Suroso, 2017).

Dari pendapat Suroso tersebut, dapat diketahui bahwa ketentuan dalam Pasal 32 ayat (2) PP Nomor 24 Tahun 1997 tersebut membuat seseorang dapat dengan mudah mengajukan 
gugatan atau keberatan atas kepemilikan suatu tanah, namun demikian kemudahan tersebut membuktikan bahwa kepastian hukum bagi pemilik tanah yang tercantum di sertipikat masih sangat kurang, meskipun menurut Pasal 19 ayat (2) UUPA huruf c, sertipikat yang diterbitkan merupakan alat pembuktian yang paling kuat.

Pendapat Suroso diperkuat oleh pendapat Tjahjo Arianto, Dosen Sekolah Tinggi Pertanahan (STPN) Yogyakarta, menurut beliau karena sistem publikasi negatif tidak menjamin kebenaran data yang disajikan, ketika terjadi pelanggaran asas nemo plus juris, kepemilikannya terlebih dahulu yang hapus, barulah kemudian dicoret dalam pendaftaran tanahnya(Arianto, 2017).

Dengan demikian ketika pengadilan telah memutus bahwa ternyata pemilik yang tercantum di dalam sertipikat bukan pemilik sebenarnya, maka yang dibatalkan adalah kepemilikannya, padahal kepemilikan juga dilekati oleh hak atas tanah, maka akan hapus keduanya. Intinya, tidak ada jaminan kepastian hukum tentang apa yang tercantum dalam sertipikat hak atas tanah, sehingga semua bukti-bukti perolehan tanah harus tetap disimpan agar suatu saat dapat dibuka. Berbeda dengan sistem publikasi positif, apabila terjadi gugatan, baik pemilik terdaftar dan pemilik sebenarnya dijamin oleh negara sampai mengenai ganti ruginya. Oleh karena itu, Kantor Pertanahan harus tetap menyimpan semua berkasnya, tidak ada batasan waktu.

Masalah lain yang bisa timbul menurut Tjahjo Arianto, yaitu ketika seseorang telah memiliki tanah sebelum lahirnya UUPA. Seseorang telah memiliki dan menguasai tanah puluhan tahun sebelum lahirnya UUPA, tanpa dilekati hak atas tanah, karena hak atas tanah baru ada ketika UUPA lahir. Ketika UUPA lahir, Kantor Pertanahan akan menetukan apakah suatu tanah merupakan tanah negara atau tanah adat. Jika ketika didaftarkan suatu tanah dinyatakan sebagai tanah negara oleh Kantor Pertanahan, maka yang diakui hanya kepemilikannya, hak atas tanahnya belum ada. Jika ketika didaftarkan suatu tanah dinyatakan sebagai tanah adat, maka atas kepemilikan tanah tersebut dapat dilekati Hak Milik. Seseorang yang memiliki tanah negara pada akhirnya pasti akan mengajukan permohonan hak atas tanah, bukan kepemilikan atas tanah. Kepemilikan lahir dari penguasaan yang sudah sekian lama, serta diakui oleh masyarakat atau komunitas di sekitarnya, barulah setelah itu negara mengakuinya sebagai tanah adat, sehingga tanah tersebut dapat dilekati Hak Milik.

Bukti bahwa sistem publikasi negatif berunsur positif menyebabkan timbulnya banyak masalah yaitu masih adanya gugatan mengenai sertipikat hak atas tanah yang sebenarnya merupakan bukti paling kuat bagi pemilik tanah, yaitu dalam rentan waktu 2015-2016 
terdapat 3 (tiga) perkara yang telah diputus mengenai sertipikat hak atas tanah di Pengadilan Negeri Semarang, serta 62 pembatalan sertipikat di Pengadilan Tata Usaha Semarang.

Menurut Eko Haryono, selaku Kepala Seksi Pendaftaran Peralihan, Pembebanan, dan PPAT Kanwil BPN Propinsi Jawa Tengah, administrasi Kantor Petanahan nantinya akan menuju ke peta tunggal. Dengan adanya peta tunggal, jika seseorang mengajukan permohonan pendaftaran atas suatu tanah, dan apabila ternyata ada sengketa mengenai tanah tersebut, maka dapat diketahui dari awal. Menurut beliau, untuk menanggulangi masalahmasalah yang timbul akibat penggunaan sistem publikasi negatif berunsur positif, Kantor Pertanahan harus melaksanakan pendaftaran tanah sesuai dengan prosedur dan langkahlangkah yang ada di dalam peraturan.(Haryono, 2017)

Menurut Pasal 31 ayat (1) Peraturan Menteri Agraria/Kepala Badan Pertanahan Nasional Nomor 3 Tahun 1997, Pendaftaran tanah harus dilaksanakan berdasarkan undangundang, selain itu Kantor Pertanahan juga telah melaksanakan asas publisitas, yaitu sebelum menerbitkan setipikat, diumumkan terlebih dahulu di kantor kelurahan dan surat kabar. Hal ini dilakukan agar pihak ketiga yang merasa mempunyai kepentingan terhadap tanah tersebut dapat mengajukan keberatan atau gugatannya.(Peraturan Menteri Agraria/Kepala Badan Pertanahan Nasional Nomor 3 Tahun 1997, n.d.)

Upaya Kantor Pertanahan dengan cara memberikan pengumuman tersebut sebenarnya sudah cukup baik, namun tetap saja ada kelemahan dari upaya tersebut, yaitu kurangnya kesadaran masyarakat untuk membaca pengumuman tersebut. Pengumuman yang dicantumkan di kantor kelurahan, belum tentu dibaca oleh setiap orang yang datang ke kantor kelurahan tersebut. Pengumuman yang dicantumkan di surat kabar pun demikian, karena hanya sebagian kecil masyarakat yang membeli dan membaca koran setiap harinya. Meskipun upaya tersebut sudah cukup bagus, namun informasi tersebut belum dapat mencakup seluruh masyarakat, sehingga meskipun sebelum diterbitkan sertipikat sudah diumumkan, tetap masih dimungkinkan adanya sengketa mengenai tanah yang diakibatkan ketidaktahuan pihak ketiga yang berkepentingan atas tanah tersebut.

Selain harus memenuhi asas publisitas, upaya lain dari Kantor Pertanahan adalah dengan menyelenggarakan pendaftaran tanah yang sesuai dengan prosedur yang telah diatur dalam peraturan perundang-undangan. Pihak Kantor Pertanahan tentu saja sedapat mungkin akan menjalankan pendaftaran tanah sesuai dengan peraturan, namun ternyata masih banyak masalah yang muncul terkait dengan sistem publikasi, seperti contoh kasus tanah tumpang tindih antara tanah milik Kisworo dengan tanah milik PT. Kekancan Mukti. Hal ini menandakan, upaya yang dilakukan Kantor Pertanahan belum maksimal, sehingga ada 
baiknya untuk meninjau kembali peraturan perundang-undangan yang mengatur mengenai pendaftaran tanah. Selain meninjau peraturan perundang-undangannya, diperlukan juga pengawasan langsung di lapangan terhadap proses pendaftaran tanah yang dilakukan oleh Kantor Pertanahan. Hal ini perlu dilakukan karena pada dasarnya, masalah atau kasus yang terjadi mengenai sertipikat hak atas tanah seperti yang terjadi antara Kisworo dan PT. Kekancan Mukti bukan disebabkan oleh kesengajaan dari masing-masing pihak. Masalah di antara keduanya muncul setelah mengetahui tanah mereka ternyata tumpang tindih satu sama lain, sedangkan tumpang tindih tersebut tentu karena adanya kesalahan ketika dilakukan pendaftaran tanah yang dilaksanakan oleh Kantor Pertanahan Kota Semarang. Oleh karena itu, seharusnya Kantor Pertanhan Kota Semarang juga menjadi Tergugat dalam kasus ini, jika Kantor Pertanahan Kota Semarang menjadi Tergugat II, putusan yang dijatuhkan hakim pun harus memberikan efek jera terhadap Kantor Pertanahan agar kedepannya lebih teliti lagi dalam melakukan pendaftaran tanah. Meskipun Indonesia menggunakan sistem publikasi negatif dimana negara tidak menjamin kebenaran data yang disajikan, BPN harus tetap cermat dalam melaksanakan pendaftaran tanah agar kedepannya tidak menyebabkan terjadinya sengketa.

\section{Akibat Hukum dari Sistem Publikasi Negatif pada Pendaftaran Tanah}

Seperti yang telah dijelaskan sebelumnya, bahwa dengan digunakannnya sistem publikasi negatif dalam pendaftaran tanah, membuat pemilik tanah yang tercantum dalam sertipikat hak atas tanah tetap dimungkinkan untuk menghadapi gugatan dari orang yang merasa berkepentingan atau merasa memiliki tanah tersebut. Pemilik tanah yang tercantum dalam sertipikat belum tentu memilliki tanah tersebut selamanya.

Meskipun Pasal 32 ayat (2) PP Nomor 24 Tahun 1997 telah mengatur bahwa 5 (lima) tahun setelah diterbitkannya sertipikat pemegang hak atas tanah tidak dapat menghadapi gugatan dari pihak yang merasa juga memiliki hak atas tanah tersebut, namun ternyata dalam prakteknya tidak sepenuhnya dijalankan sesuai dengan ketentuan tersebut. Sebagaimana pendapat Eko Haryono, meskipun menurut ketentuannya setelah 5 (lima) tahun tidak dapat digugat lagi, namun dalam kenyataannya meskipun telah lewat dari 5 (lima) tahun, pemilik tanah yang tercantum di dalam sertipikat tetap dimungkinkan menghadapi suatu gugatan asalkan penggugat memiliki bukti yang valid. Hal ini dikarenakan ketika pemilik tanah mendaftarkan tanahya, belum tentu ia beritikad baik. Itikad baik dari pemilik terdaftar sangat dibutuhkan, karena tetap dimungkinkan ia mendaftarkan tanah tersebut dengan surat-surat atau data-data yang palsu. Kantor 
Pertanahan tidak akan dapat memastikan apakah surat-surat atau data-data tersebut asli atau palsu. Maka dari itu, seseorang tetap dapat mengajukan gugatan, meskipun telah lewat dari 5 (lima) tahun karena dikhawatirkan adanya itikad tidak baik dari pemilik terdaftar(Haryono, 2017).

Menurut analisis penulis, perbedaan ketentuan PP Nomor 24 Tahun 1997 dengan yang terjadi dalam praktek membuat unsur positif semakin tidak terlihat dalam sistem publikasi yang digunakan di Indonesia. Menurut penjelasan Pasal 32 ayat (2), adanya unsur positif dalam sistem publikasi tersebut adalah meskipun berpegang pada sistem publikasi negatif, namun tetap berusaha untuk memberikan jaminan kepastian hukum kepada pemilik. Tetapi jika ternyata di dalam praktek setelah 5 (lima) tahun pun masih dapat digugat jika ada bukti yang kuat, artinya jaminan kepastian hukum pada pemilik masih kurang. Selain itu, dapat dikatakan hal tersebut melanggar ketentuan yang ada di dalam Pasal 32 ayat (2) PP Nomor 24 Tahun 1997. Pelanggaran tersebut memang bertujuan untuk menjamin kepastian hukum bagi pemilik tanah yang sebenarnya, namun dengan demikian unsur positif yang ada dalam sistem publikasi di Indonesia semakin tidak terlihat, sehingga sistem publikasi yang digunakan di Indonesia terkesan seperti murni negatif.

Sebenarnya Indonesia sedang menuju ke sistem publikasi positif, karena tidak dapat dipungkiri bahwa sistem publikasi positif memberikan jaminan kepastian hukum yang lebih kuat pada pemilik tanah. Pada sistem publikasi positif baik terdaftarnya hak maupun kepemilikan tidak dapat diganggu gugat lagi meskipun pemilik melanggar asas nemo plus juris atau pun apabila pemilik tanah mendapatkan tanah tersebut dari seseorang yang melanggar asas nemo plus juris. Hal ini bertujuan untuk meberikan jaminan kepastian hukum bagi pemilik tanah dapat diwujudkan.

Indonesia masih menggunakan sistem publikasi negatif, dimana pemilik yang tercantum dalam sertipikat hak atas tanah masih dapat menghadapi kemungkinan untuk menghadapi gugatan. Ketika pemiik tanah terbukti melanggar asas nemo plus juris atau ia terbukti mendapatkan tanah tersebut dari seseorang yang telah melanggar asas nemo plus juris melalui putusan pengadilan, maka baik hak kepemilikan maupun hak atas tanahnya menjadi hapus. Terdaftarnya orang tersebut dalam sistem buku tanah hapus, otomatis kepemilikannya juga hapus, karena yang terdaftar adalah kepemilikan dan hak atas tanah. Selain mencegah pelanggaran asas nemo plus juris, sistem publikasi negatif berunsur positif juga dimaksudkan untuk melindungi orang yang memperoleh suatu tanah dengan itikad baik, sehingga seseorang yang memperoleh tanah dengan itikad buruk juga dapat hapus kepemilikan dan hak atas tanahnya. 


\section{Simpulan}

Sertipikat hak atas tanah masih dapat diubah meskipun sertipikat hak atas tanah merupakan tanda bukti yang paling kuat atas kepemilikan tanah karena sistem publikasi yang digunakan di Indonesia adalah sistem publikasi negatif berunsur positif. Dalam sistem publikasi negatif, negara tidak menjamin kebenaran data yang disajikan.Sertipikat hak atas tanah merupakan alat pembuktian yang kuat, bukan alat pembuktian yang mutlak. Orang yang namanya tercantum sebagai pemegang hak dalam buku tanah dan sertifikat selalu menghadapi kemungkinan gugatan dari pihak lain yang merasa berkepentingan atas tanah tersebut, sehingga penggunaan sistem publikasi negatif menyebabkan kurangnya jaminan kepastian hukum bagi pemilik tanah.

Akibat hukum dari sistem publikasi negatif pada pendaftaran tanah adalah ketika pemiik tanah terbukti melanggar asas nemo plus juris atau ia terbukti mendapatkan tanah tersebut dari seseorang yang telah melanggar asas nemo plus juris melalui putusan pengadilan, maka baik hak kepemilikan maupun hak atas tanahnya menjadi hapus. Terdaftarnya orang tersebut dalam sistem buku tanah hapus, otomatis kepemilikannya juga hapus, karena yang terdaftar adalah kepemilikan dan hak atas tanah. Sistem publikasi negatif berunsur positif selain mencegah terjadinya pelanggaran asas nemo plus juris, juga untuk melindungi pemilik tanah yang memperoleh tanah yang betul-betul memperoleh tanah dengan itikad baik, sehingga seseorang yang memiliki tanah dengan itikad buruk baik kepemilikan dan hak aas tanahnya dapat hapus.

\section{DAFTAR PUSTAKA}

\section{Buku}

Achmad, M. F. N. dan Y. (2010). Dualisme Penelitian Hukum Normatif dan Hukum Empiris. Yogyakarta: Pustaka Pelajar.

Effendie, B. (1993). Pendaftaran Tanah di Indonesia dan Peraturan Pelaksananya. Bandung: Penerbit Alumni.

Harsono, B. (2008). Hukum Agraria Indonesia: Sejarah Pembentukan Undang-undang Pokok Agraria, Isi, dan Pelaksanaannya. Jakarta: Djambatan.

HS, S. (2013). Penerapan Teori Hukum pada Penelitian, Tesis, dan Disertasi. Jakarta: Raja

Grafindo Persada.

Murdiyatmoko, J. (2007). Sosiologi Memahami dan Mengkaji Masyarakat. Jakarta: Grafindo Media 
Pratama.

Santoso, U. (2010). Pendaftaran dan Peralihan Hak atas Tanah. Jakarta: Prenada Media Group.

Santoso, U. (2014). Hukum Agraria: Kajian Komprehensif. Jakarta: Kencana.

Soemitro, R. H. (1990). Metodologi Penulisan Hukum. Jakarta: Ghalia.

Suroso. (2017). Wawancara Pihak Kantor Pertanahan Kota Semarang. Semarang.

Susanto, B. (2014). Kepastian Hukum Sertipikat Hak atas Tanah berdasarkan Peraturan Pemerintah Nomor 24 Tahun 1997. DIH, Jurnal Hukum, 10(20), 76-82.

Sutedi, A. (2010). Peralihan Hak atas Tanah dan Pendaftarannya. Jakarta: Sinar Grafika.

Sutedi, A. (2014). Sertifikat Hak atas Tanah. Jakarta: Sinar Grafika.

\section{Artikel Jurnal}

Kaunang, M. C. (2016). Proses Pelaksanaan Pendaftaran Tanah menurut Peraturan Pemerintah Nomor 24 Tahun 1997. Lex Crimen, 5(4). Retrieved from https://media.neliti.com/media/publications/145459-ID-proses-pelaksanaan-pendaftarantanah-men.pdf

Oelom, F. (2015). Jaminan Kepastian Hukum Hak atas Tanah dalam Sistem Pendaftaran Tanah Negatif bertendensi Positif. Retrieved from https://media.neliti.com/media/publications/35684-ID-jaminan-kepastian-hukum-hak-atastanah-dalam-sistem-pendaftaran-tanah-negatif-be.pdf

Widayanti, F. (2015). Sistem Publikasi Pendaftaran Tanah Menurut Undang-undang Nomor 5 Tahun 1960 tentang Peraturan Dasar Pokok-pokok Agraria (UUPA). Repository Unair. Retrieved from http://repository.unair.ac.id/33918/

Widyani, I. D. A. (2015). Kepastian Hukum Sistem Publikasi dalam Pendaftaran Tanah di Indonesia menurut UU RI Nomor 5 Tahun 1960 tentang Pokok-pokok Agraria. Jurnal Hukum Universitas Kristen Indonesia, 1(3).

\section{Undang-undang dan Peraturan}

Undang-undang Dasar Negara Republik Indonesia Tahun 1945. (n.d.).

Undang-undang Nomor 5 Tahun 1960 tentang Peraturan Dasar Pokok-pokok Agraria. (n.d.).

Peraturan Pemerintah Nomor 10 Tahun 1961 tentang Pendaftaran Tanah. (n.d.).

Peraturan Pemerintah Nomor 24 Tahun 1997 tentang Pendaftaran Tanah. (n.d.).

Peraturan Menteri Agraria/Kepala Badan Pertanahan Nasional Nomor 3 Tahun 1997. (n.d.).

\section{Wawancara}

Arianto, T. (2017). Wawancara Dosen Sekolah Tinggi Pertanahan (STPN) Yogyakarta. 
Yogyakarta.

Haryono, E. (2017). Wawancara Kepala Seksi Pendaftaran Peralihan, Pembebanan, dan PPAT Kanwil BPN Jawa Tengah. Semarang. 